\title{
Human Security di Papua pada Masa Pemerintahan Jokowi: Tinjauan terhadap Political Security di Papua
}

\author{
Ignatius Yonatan S \\ 2016330164 \\ Mahasiswa Jurusan Ilmu Hubungan Internasional, Fakultas Ilmu Sosial dan Ilmu \\ Politik \\ Universitas Katolik Parahyangan
}

\begin{abstract}
The continuing conflict in Papua is a problem that should be given more attention by the current Indonesian government. The problem is not merely a matter of integrity, and economy. However, it is also about human security's matter, especially, political security in Papua. Until now, Papuans still face different treatment than those in other parts of Indonesia. Violence and abuse of human rights, also other form of cruelty still happen there. As president of Indonesia, Jokowi is expected to be able to solve the political security's matter in Papua. However, it should be admitted that solving political security's matter in Papua is not that easy. Nevertheless, Jokowi has shown good intentions to restore Indonesia's relations with Papua through economic approach. This research will discuss about how human security in Papua under Jokowi with focus on the review of political security in Papua.
\end{abstract}

Keyword : political security, human security, Papua, Indonesia

\section{Pendahuluan}

Permasalahan Papua belum dapat terselesaikan hingga saat ini dan tengah menjadi sorotan media massa internasional. Hal ini setidaknya dapat terlihat dari banyaknya pengunggahan berita di media massa mengenai kesenjangan ekonomi, kelaparan, dan terutama, permasalahan kekerasan dan pelanggaran terhadap hak asasi manusia yang terjadi di sana.

Sejak masuknya Papua ke Indonesia, masyarakat Papua sudah mendapatkan perlakuan yang kurang berkenan. Pengekangan terhadap hak kebebasan berpolitik seperti act of no choice pada tahun 1969, tahanan politik, serta pengekangan terhadap kebebasan berpendapat dan berkumpul warga Papua masih ditemui setidaknya sampai pada tahun 2013; pelanggaran terhadap hak asasi manusia seperti penyiksaan dan penganiayaan, pembunuhan kilat, dan genosida pada akhir tahun

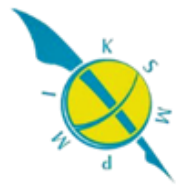


1970an, serta peristiwa berdarah lainnya. Hal ini menyebabkan terus terjadinya ketegangan situasi antara Pemerintah Indonesia dengan Papua yang menyebabkan ketidakharmonisan hubungan di antara keduanya.

Permasalahan Papua kini menjadi lebih rumit karena Indonesia mendapat kecaman dari pihak eksternal mengenai banyaknya pelanggaran hak asasi manusia di Papua. Contohnya adalah kecaman terhadap pelanggaran hak asasi manusia yang berasal dari organisasi-organisasi internasional, diantaranya adalah International Coalition for Papua (ICP), dan juga dukungan kepada Papua yang berasal dari kelompok negara-negara tetangga Pasifik, yakni Melanesian Spearhead Group (MSG).

Penting bagi seluruh pihak untuk memahami secara mendalam mengenai apa yang sebenarnya terjadi di Papua dan hal-hal yang menjadi akar dari permasalahan antara Papua dan Indonesia dengan melihat sejarah. Dengan memiliki pemahaman yang baik, diharapkan hal ini dapat membantu tercapainya keteraturan dan solusi atas konflik yang terus-menerus terjadi di Papua. ${ }^{1}$ Sudah cukup bagi Papua untuk hidup dibawah tekanan dan menyaksikan teman, rekan, bahkan anggota keluarga menjadi korban atas konflik yang terus terjadi.

Sebagai Presiden Indonesia yang dianggap paling memungkinkan untuk membangun keharmonisan antara Indonesia dan Papua, Jokowi perlu memerhatikan dan meningkatkan human security di Papua guna menjaga stabilitas dan keamanan nasional. Saat ini, Jokowi telah menunjukkan usahanya untuk membangkitkan Papua dari keterpurukan. Hal ini dibuktikan dengan digalakkannya pembangunan infrastruktur di Papua yang bertujuan untuk membuka akses guna meningkatkan perekonomian dan pembangunan di Papua, juga ditujukan untuk menghidupkan

\footnotetext{
${ }^{1}$ Asian Human Rights Commission, The Neglected Genocide : Human Rights Abuse Against Papuans In The Central Highlands (Hong Kong : Clear-Cut Publishing and Printing Co, 2013), 59
} 
Papua dengan membuka isolasi wilayah pedalaman di Papua. ${ }^{2}$ Tidak hanya di bidang ekonomi saja, Jokowi juga mengupayakan adanya peningkatan pelayanan pendidikan serta kesehatan di Papua. Namun, persoalan Papua tidak sesederhana permasalahan keterbatasan akses terhadap kebutuhan dasar saja, sebab masyarakat Papua sampai saat ini masih mendapatkan perlakuan yang kurang berkenan. Ditambah lagi masih terdapatnya persoalan politik, hukum, dan keamanan. ${ }^{3}$ Oleh sebab itu, sangat diperlukan adanya peningkatan terhadap political security di Papua guna menjaga stabilitas dan keamanan nasional.

Sampai saat ini, istilah 'Papua' sudah beberapa kali diganti oleh Pemerintah Indonesia. Setidaknya sejak tahun 1969 sampai saat ini, istilah 'Papua' telah mengalami empat kali pergantian nama. Berdasarkan perubahan terakhir, yakni pada tahun 2003, Pemerintah Indonesia memisahkan bagian timur dari Papua, membuat Papua dibagi menjadi dua provinsi yang berbeda, yakni Provinsi Papua Barat, dan Provinsi Papua. ${ }^{4}$ Dalam jurnal ini, penggunaan kata 'Papua' merujuk pada kedua provinsi tersebut guna memudahkan penulis dalam membuat jurnal ini.

\section{Pendekatan Human Security}

Human security merupakan sebuah pendekatan keamanan non-tradisional yang muncul sebagai tanggapan atas adanya perubahan fokus terhadap ancaman keamanan, dimana pada awalnya hanya berfokus pada isu militer (tradisional), menjadi isu-isu kemanusiaan, ekonomi, lingkungan, dan kesehatan (nontradisional). Setelah berakhirnya perang dingin yang ditandai dengan runtuhnya Uni Soviet, dunia internasional merasakan adanya ancaman-ancaman baru yang tidak dapat diselesaikan hanya melalui konsep keamanan tradisional yang hanya berfokus

\footnotetext{
2 “Tokoh Papua : Dari 7 Presiden Jokowi Paling Sering ke Papua," Tempo, 19 Mei 2017, https://nasional.tempo.co/read/876865/tokoh-papua-dari-7-presiden-jokowi-paling-seringke-papua (Diakses pada 20 November 2017)

3 Abraham Utama, "Wajah Muram Papua di Tangan Jokowi," CNNIndonesia, 20 Oktober 2016, https://www.cnnindonesia.com/nasional/20161019205839-20-166636/wajah-murampapua-di-tangan-jokowi/ (Diakses pada 21 November 2017)

${ }^{4}$ Asian Human Rights Commission, The Neglected Genocide, 60
}

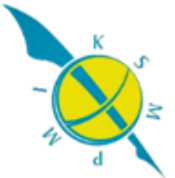


kepada militer. Pada tahun 1994, United Nations Development Program (UNDP) mengidentifikasikan pendekatan human security sebagai cara untuk melihat konsep keamanan melalui perspektif yang lebih luas, yakni mencakup keamanan terhadap ancaman kemiskinan, kelaparan, penyakit, akses terhadap air bersih, penindasan, kekerasan, genosida, dan pelanggaran terhadap hak asasi manusia. ${ }^{5}$

Keamanan merupakan sebuah konsep yang berhubungan erat dengan usaha untuk menciptakan pertahanan maupun pencegahan terhadap ancaman. ${ }^{6}$ Oleh sebab itu, human security adalah sebuah pendekatan keamanan yang menaruh fokus terhadap isu non-tradisional, dimana perhatian utamanya adalah keamanan pada tingkat individu atau manusia. Pembentukan konsep human security dilatar belakangi oleh adanya kebutuhan untuk melindungi nilai-nilai kemanusiaan yang dianut. Untuk memperkuat konsepnya, human security memiliki Universal Declaration of Human Rights and Responsibility to Protect Doctrine sebagai landasan dan dasar hukumnya. Berdasarkan UNDP, sebuah negara dapat diukur tingkat keberhasilan human security-nya melalui human development index (HDI), kesempatan pendidikan, dan angka harapan hidup. ${ }^{7}$

Konsep human security sendiri merupakan konsep keamanan yang sangat luas cakupanya. Berdasarkan UNDP terdapat tujuh hal yang dianggap sebagai ancaman dan merupakan cakupan bagi pendekatan human security: ${ }^{8}$

1. Keamanan ekonomi, yang menaruh perhatian utama pada ancaman kemiskinan, dimana masyarakat pada suatu negara masih memiliki tingkat pendapatan yang sangat rendah.

2. Keamanan pangan, yang perhatian utamanya tertuju kepada masalah kelaparan, yakni dimana masyarakat tidak memiliki akses untuk memenuhi kebutuhan makanan.

\footnotetext{
5 Shahrbanou Tadjbakhsh dan Anuradha M. Chenoy, Human Security : Concepts and Implications (New York: Routledge, 2007), 1

${ }^{6}$ Ibid, 4

${ }^{7}$ Derek S.R dan Kathleen A. M, Human Security In A Borderless World (USA : Westview Press, 2011), 3

${ }^{8}$ Shahrbanou Tadjbakhsh dan Anuradha M. Chenoy, Human Security, 15-16
}

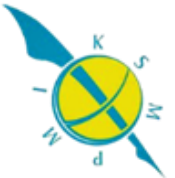


3. Keamanan kesehatan, memiliki fokus pada ancaman penyakit menular berbahaya. Tidak dapat dipungkiri bahwa semakin berkembangnya zaman, semakin banyak penyakit yang muncul dan penyebarannya dapat dikatakan sangat cepat, bahkan dapat menembus batas negara dengan kurun waktu yang cepat.

4. Keamanan lingkungan, yang perhatian utamanya tertuju pada isu degradasi lingkungan yang terjadi seperti polusi, gangguan ekosistem, dan bahkan bencana alam.

5. Keamanan personal, yakni mengenai hal-hal yang dianggap sebagai ancaman dalam konsep keamanan personal, seperti misalnya ancaman kekerasan, baik yang datang dari kelompok atau individu tertentu, seperti misalnya geng maupun yang datang dari aparat negara seperti polisi dan militer.

6. Keamanan komunitas, fokus pada ancaman bagi keamanan komunitas seperti terjadinya konflik antar etnis atau kelompok, maupun diskriminasi terhadap suatu etnis atau kelompok tertentu yang dapat menyebabkan terjadinya disintegrasi, pengungsian, kelompok pemberontak, bahkan konflik bersenjata.

7. Keamanan politik, menaruh perhatian pada ancaman tekanan politik, pelanggaran hak asasi manusia, kekerasan militer, praktik penyiksaan, perlakuan buruk, dan penahanan politik.

Berdasarkan penjabaran diatas kita dapat melihat bahwa human security memiliki cakupan yang cukup luas. Untuk mempertajam jurnal ini, penulis akan memfokuskan pada keamanan politik sebagai bahasan utamanya.

\section{Sejarah Masuknya Papua ke Indonesia dan Human Security di Papua Saat Itu}

Seperti daerah lain di Indonesia, Papua pernah menjadi daerah jajahan Belanda. Permasalahan Papua sebagai bagian dari Indonesia awalnya diangkat oleh Soekarno yang meyakini bahwa Indonesia merupakan penerus Dutch East yang




wilayahnya kekuasaannya mencakup daerah Sumatra hingga pulau New Guinea, sehingga Soekarno hendak memperjuangkan Papua sebagai isu integritas bangsa. ${ }^{9}$ Pada waktu yang sama, Belanda mengakui bendera Bintang Kejora sebagai identitas masyarakat Papua. Soekarno melihat hal ini sebagai ancaman terhadap keamanan nasional dan menanggapi ancaman ini dengan meluncurkan perintah untuk membebaskan Papua melalui pidato Trikora. ${ }^{10}$ Sejak saat inilah, mulai terjadi banyak benturan antara Pemerintah Indonesia dengan masyarakat Papua.

Masyarakat Papua mendapat perlakuan yang kurang berkenan sejak masuknya Papua ke Indonesia. Misalnya, dalam hal berpolitik, hak masyarakat Papua sangat dibatasi, seperti dengan adanya "act of no choice", dimana yang seharusnya terjadi adalah "act of free choice".

Dalam usahanya untuk mengambil alih Papua dari tangan Belanda, Indonesia pada masa Pemerintahan Soekarno banyak menggunakan tekanan militer yang ditujukan untuk mengancam pemerintah Belanda. Namun, permasalahan Indonesia dengan Belanda mengenai Papua tidak dapat diselesaikan. Sampai akhirnya pada masa Soeharto, pihak Amerika Serikat turut turun tangan untuk membantu mengatasi permasalahan ini melalui PBB. Papua akhirnya diambil alih sementara oleh United Nations Temporary Executive Authority (UNTEA) pada tahun 1962 sampai 1963. ${ }^{11}$ Setelah UNTEA memberikan alih penguasaan kepada Indonesia, pemerintah Indonesia kembali mengupayakan usahanya agar Papua bergabung menjadi bagian dari Indonesia melalui cara-cara yang melibatkan kekerasan dan paksaan. Banyaknya tekanan yang dilakukan secara terus menerus pada saat itu menyebabkan terbentuknya kelompok separatis yang saat ini dikenal dengan Organisasi Papua Merdeka (OPM).

Banyak orang Papua dari seluruh penjuru Papua pada saat itu turut bergabung dengan kelompok ini untuk mendukung kebebasan Papua dari

\footnotetext{
${ }^{9}$ Asian Human Rights Commission, The Neglected Genocide, 62-63

${ }^{10}$ Ibid, 63

${ }^{11}$ Elizabeth Brundige dkk, Indonesian Human Rights Abuses in West Papua, 14-15
}

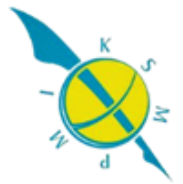


banyaknya tekanan pemerintah Indonesia. ${ }^{12}$ Respon yang diberikan oleh pemerintah Indonesia kepada OPM dapat dikatakan tidak bijak, dimana dalam usahanya untuk menekan OPM, pemerintah Indonesia memeperlakukan warga sipil biasa sama halnya seperti terhadap kelompok OPM, yang menyebabkan banyak orang Papua yang terbunuh pada saat terjadi perjuangan bersenjata di Papua. Data menyatakan bahwa sampai saat ini, sudah lebih dari 500 ribu warga sipil terbunuh dalam upaya yang dilakukan oleh Indonesia untuk menekan kelompok antipemerintah di Papua. Ribuan orang lainnya dinyatakan hilang setelah menjadi tahanan politik dan banyak juga yang mendapatkan perlakuan buruk seperti disiksa, dianiaya, bahkan diperkosa. Pada masa tersebut, perlakuan seperti ini bahkan sudah menjadi hal yang biasa bagi masyarakat Papua. ${ }^{13}$

Untuk memenangkan suara pemilihan dan menekan sentimen antiPemerintah Indonesia pada saat itu, akhirnya militer Indonesia mulai memberikan ancaman kepada orang Papua bahwa mereka akan menembak orang Papua yang tidak memilih Papua menjadi bagian dari Indonesia. ${ }^{14}$ Berdasarkan pemilihan yang hanya dihadiri oleh sebagian kecil perwakilan masyarakat Papua dan tekanan yang diberikan kepada mereka, Papua memilih untuk tetap menjadi bagian dari Indonesia. Peristiwa ini sampai sekarang masih diingat oleh masyarakat Papua sebagai act of no choice.

\section{Human Security di Papua Tahun 1977 - 2014}

Papua merupakan daerah yang sangat kaya akan sumber daya alamnya, namun sangat disayangkan karena di sana banyak sekali terjadi pelanggaran terhadap keamanan politik, seperti di antaranya adalah tindak kekerasan dan pelanggaran terhadap hak asasi manusia. Beberapa tahun setelah Papua secara resmi menjadi bagian dari Indonesia, masyarakat Papua mengalami masa terkelam dalam

\footnotetext{
${ }^{12}$ Ibid

13 "Human Rights," FreeWestPapua, https://www.freewestpapua.org/info/human-rights/ (Diakses pada 20 Oktober 2017)

${ }^{14}$ Elizabeth Brundige dkk, Indonesian Human Rights, 18
} 
sejarah hidupnya, yakni pada tahun 1977 sampai 1978 terjadi genosida besarbesaran di Pegunungan Tengah. Peristiwa ini terjadi lantaran Pemerintah Indonesia tengah mengadakan operasi militer yang ditujukan untuk menjaga keamanan nasional dari adanya kelompok OPM yang dianggap mampu mengganggu stabilitas dan keamanan nasional Indonesia. ${ }^{15}$

Pada tahun 1977 sampai 1978, militer Indonesia mendapat banyak serangan yang berasal dari kelompok OPM. Namun respon yang diberikan oleh militer Indonesia pada saat itu dirasa terlalu berlebihan, sehingga menyebabkan banyaknya korban jiwa. Serangan pertama yang yang dilakukan oleh OPM adalah pada 20 April 1977, dimana serangan tersebut dilakukan ketika beberapa personel militer Indonesia sedang bermain sepak bola bersama warga di Kampung Kobakma. ${ }^{16}$ Setelah OPM kembali melakukan beberapa serangan, militer Indonesia akhirnya mengambil tindakan tegas untuk menghentikan serangan tersebut dengan meningkatkan jumlah militer di sana. Tidak berhenti sampai di sana, militer Indonesia pada saat itu juga menggunakan pesawat dan menjatuhkan bom di beberapa titik. ${ }^{17}$ Operasi ini dilakukan tanpa pandang bulu, sehingga warga sipil yang tidak memiliki keterkaitan dengan OPM juga ikut terbunuh. Data menyatakan setidaknya sebanyak 4146 orang Papua, baik yang merupakan anggota aktif kelompok separatis OPM, maupun warga sipil dari seluruh penjuru di Pegunungan Tengah telah menjadi korban dalam peristiwa berdarah ini. ${ }^{18}$

Tahun demi tahun telah berlalu, namun Papua masih mendapatkan perlakuan yang berbeda dari daerah-daerah Indonesia yang lainnya. Terutama bagi kebebasan berpolitik, Papua masih mendapatkan tekanan terhadap kebebasan berekspresi. Selain itu, kekerasan dan tindak sewenang-wenang yang dilakukan oleh militer, serta pelanggaran hak asasi manusia masih terus terjadi di Papua, setidaknya sampai tahun 2013. Data menyatakan, sejak 2011 sampai 2013, terdapat 13 kasus

\footnotetext{
${ }^{15}$ Asian Human Rights Commission, The Neglected Genocide), 68

${ }^{16}$ Ibid, 69

${ }^{17}$ Ibid, 70-72

${ }^{18}$ Ibid, 68
} 
pembunuhan kilat terhadap 25 orang Papua yang korbannya merupakan aktivis maupun warga sipil. Terdapat pula 17 kasus penyiksaan, dimana 10 diantaranya merupakan kasus yang dilakukan oleh aparat kepolisian Indonesia. Serta pembatasan hak untuk menyatakan pendapat. Hal ini dibuktikan dengan penangkapan beberapa orang karena menyuarakan hak mereka. Beberapa orang yang merupakan anggota keluarga dari aktivis pun turut ditangkap oleh polisi karena dianggap membahayakan keamanan negara. ${ }^{19}$

Pengekangan terhadap kebebasan berekspresi masih dapat ditemui di Papua, dimana biasanya aktivis-aktivis yang menyuarakan pendapatnya berakhir di balik jeruji sebagai tahanan politik. Penangkapan dan penahanan ini biasanya diikuti oleh tindak kekerasan, penyiksaan, dan penganiayaan, yang tentunya hal ini sangat bertentangan dengan hak asasi manusia. ${ }^{20}$ Tidak berhenti disana, jurnalis di Papua juga mendapatkan perlakuan yang kurang berkenan. Mereka menghadapi ancaman dan intimidasi, dan tidak jarang mendapatkan perlakuan kasar dari aparat negara. ${ }^{21}$

Permasalahan mengenai pembunuhan kilat juga menunjukkan bahwa sampai pada tahun 2013, Papua masih belum mendapatkan perlindungan yang sama dibandingkan dengan daerah lain di Indonesia dari Pemerintah Indonesia. ${ }^{22}$ Keadaan dan situasi tersebut menyebabkan masyarakat asli Papua masih hidup dalam tekanan dan ancaman yang terus-menerus terjadi sampai saat ini.

\section{Human Security di Papua Pada Masa Pemerintahan Jokowi}

Jokowi merupakan Presiden Indonesia yang sampai saat ini dapat dikatakan paling menunjukkan kepeduliannya pada Papua. Hal ini dapat dibuktikan dengan maraknya pembangunan infrastruktur di Papua yang ditujukan untuk meningkatkan akses ekonomi disana. Sebagai Presiden Indonesia, Jokowi merupakan tokoh yang

\footnotetext{
${ }^{19}$ Human Rights and Peace for Papua : The International Coalition For Papua, Hak Asasi Manusia di Papua 2013 (Jenewa : ICP dan Franciscans International, 2013), 12

${ }^{20}$ Ibid, 12

${ }^{21}$ Ibid, 18

${ }^{22}$ Ibid, 24
} 
paling sering mengunjungi Papua dibanding presiden-presiden sebelumnya.

Setidaknya sampai saat ini, Jokowi sudah mengunjungi Papua sebanyak tujuh kali.

Kunjungan pertama Jokowi ke Papua pertama kali dilakukan pada awal periode pemerintahannya, yakni pada bulan Desember tahun 201423, dan kunjungan ketujuhnya belum lama dilakukan, yakni pada bulan Mei 2017 lalu. ${ }^{24}$

Selama tiga tahun berjalan masa pemerintahannya, Jokowi telah menunjukkan niat untuk meningkatkan taraf human security di Papua, yang diwujudkan dengan usaha nyata yang Beliau lakukan. Jokowi kini tengah menggiatkan pembangunan di Papua melalui pembangunan infrastruktur seperti jalan raya, lapangan terbang, dan sebagainya. ${ }^{25}$ Usaha yang dilakukan Jokowi sejauh ini mendapatkan tanggapan yang positif dari masyarakat Indonesia, seperti salah satunya adalah tokoh masyarakat Papua yang juga merupakan mantan Duta Besar Indonesia untuk Kolombia, Michael Manufandu, yang menyatakan apresiasinya terhadap keseriusan Jokowi dalam membuka isolasi wilayah pedalaman Papua melalui pembangunan infrastruktur. ${ }^{26}$ Hal ini sekaligus menunjukkan bahwa saat ini Pemerintah Indonesia turut memberikan perhatian serius kepada Papua.

Wilayah Pegunungan Tengah yang dikatakan sebagai daerah yang memiliki keterbatasan terhadap segala akses, merupakan daerah yang paling mengalami ketertinggalan dan ketimpangan pembangunan. Namun berkat Jokowi, Pegunungan Tengah saat ini telah menjadi prioritas Pemerintah Indonesia. Data menyatakan

23 "Presiden Jokowi Tiba di Papua," BBCIndonesia, 27 Desember 2014, http://www.bbc.com/indonesia/berita_indonesia/2014/12/141227_jokowi_papua_kunjung (Diakses pada 27 November 2017)

${ }^{24}$ Alfred Karafir, "Kunjungan Ketujuh Presiden Jokowi Bangun Indonesia dari Papua," Papuanews, 10 Mei 2017, https://papuanews.id/2017/05/10/kunjungan-ketujuh-presidenjokowi-baangun-indonesia-dari-papua/ (Diakses pada 27 november 2017)

25 Tokoh Papua, https://nasional.tempo.co/read/876865/tokoh-papua-dari-7-presidenjokowi-paling-sering-ke-papua (Diakses pada 20 November 2017)

26 Tokoh Papua, https://nasional.tempo.co/read/876865/tokoh-papua-dari-7-presidenjokowi-paling-sering-ke-papua (Diakses pada 20 November 2017)

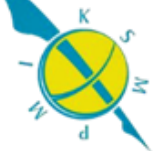


bahwa berbagai jenis infrastruktur seperti jalan raya, jembatan, dan lapangan terbang kini tengah dibangun di wilayah ini. ${ }^{27}$

Dapat dikatakan bahwa pada masa pemerintahan Jokowi, Papua sudah mendapatkan perhatian yang serius guna membuka Papua dari keterisolasiannya. Meskipun demikian, permasalahan Papua bukanlah sekedar masalah ketertinggalan terhadap akses ekonomi, melainkan Papua sampai saat ini masih mendapati perlakuan yang berbeda khususnya pada permasalahan politik dan kemanusiaan, seperti adanya tindak kekerasan, penganiayaan, serta pelanggaran terhadap hak asasi manusia.

Terhitung sejak tahun 1969, Papua sudah secara resmi merupakan bagian dari Indonesia, namun sampai tahun 2017, kondisi keamanan politik di Papua masih belum mendapatkan perhatian yang cukup dari Pemerintah Indonesia. Setidaknya sampai pada tahun 2014, ruang berpolitik masyarakat Papua masih sangat ditekan oleh Pemerintah Indonesia. Tidak berhenti sampai di sana, banyak sekali kasus pelanggaran hak asasi manusia serta konflik yang berkepanjangan yang masih terjadi. Berdasarkan pernyataan yang dikemukakan oleh gereja serta organisasi hak asasi manusia di Papua, tercatat bahwa adanya kenaikan jumlah kekerasan horizontal antara masyarakat asli Papua dengan pendatang. ${ }^{28}$ Sangat memprihatinkan bahwa kekerasan telah menjadi hal yang biasa di Papua.

Tindak penangkapan terhadap aktivis yang terjadi di Papua masih memprihatinkan. Para tahanan politik (tapol) mendapatkan perlakuan yang kurang berkenan. Jumlah kasus pembunuhan yang terdokumentasi pada tahun 2014 dan 2015 menunjukkan bahwa paling tidak setiap bulannya terdapat satu orang menjadi korban yang berkaitan dengan penggunaan kekerasan dan senjata api yang berlebihan dimana semua korban dalam kasus ini adalah penduduk asli Papua. ${ }^{29}$ Kekerasan dan pelanggaran terhadap hak asasi manusia serta kebebasan

\footnotetext{
${ }^{27}$ Ibid.

${ }^{28}$ International Coalition for Papua, Hak Asasi Manusia di Papua 2015 (Genewa : ICP dan Franciscans International, 2015), 4

${ }^{29}$ Ibid, 10
} 
berpendapat tidak hanya didapati oleh warga asli Papua, namun juga kepada wartawan lokal dan asing. ${ }^{30}$

Berdasarkan penjabaran data di atas, perlu diakui bahwa sampai saat ini permasalahan human security, khususnya terhadap keamanan politik di Papua, belum mendapatkan perhatian yang cukup dari Pemerintah Indonesia. Melihat masih adanya tekanan, ancaman, kasus kekerasan, penganiayaan, dan pelanggaran hak asasi manusia di Papua, dapat dikatakan bahwa pihak Indonesia masih lebih mementingkan national security dibandingkan dengan human security.

Padahal, perlu diakui bahwa dalam dunia yang modern ini, masalah human security merupakan hal yang penting untuk diperhatikan dan dicari penyelesaiannya. Bagaimanapun, Papua merupakan bagian dari Indonesia. Oleh sebab itu, Pemerintah Indonesia juga harus memperhatikan human security di Papua. Pemerintahan Presiden Jokowi sudah memulai langkah yang baik untuk memperbaiki hubungan Indonesia dengan Papua melalui pendekatan keamanan ekonomi, namun keamanan politik di Papua sendiri masih sangat perlu diperhatikan. Sampai saat ini, permasalahan politik dan keamanan di Papua masih menjadi perhatian besar bagi Indonesia, dimana praktik kekerasan terhadap warga asli Papua masih terjadi. ${ }^{31}$ Meskipun demikian, usaha Jokowi dalam menanggapi banyaknya kasus hak asasi manusia dapat dibuktikan dengan tindakan Jokowi membebaskan lima tahanan politik (tapol) dan membuka keterbukaan bagi peneliti dan wartawan asing pada tahun 2015..$^{32}$

\section{Kesimpulan dan Saran}

Berdasarkan pembahasan di atas, maka dapat disimpulkan bahwa human security di Papua pada bidang keamanan politik masih jauh dari kata layak. Dalam menanggapi permasalahan di Papua, Pemerintah Indonesia, baik secara sadar atau

\footnotetext{
${ }^{30}$ Ibid, 10

${ }^{31}$ International Coalition for Papua, Human Rights In West Papua 2017 (Geneva : ICP, 2017), 8

32 Ibid.
} 
tidak, seringkali masih mengaitkannya dengan masalah keamanan nasional. Padahal dalam perkembangan dunia saat ini, Indonesia sebagai sebuah negara dirasa perlu untuk memperhatikan human security di wilayah negaranya. Pemerintah Indonesia perlu untuk memberikan perhatian yang lebih terhadap banyaknya kasus pelanggaran terhadap keamanan politik di Papua.

Sebagai Presiden Indonesia yang sedang menjabat pada periode kali ini, Jokowi telah menunjukkan niat dalam membuka Papua dari keterisolasiannya. Hal ini ditunjukkan melalui upaya Jokowi dalam meningkatkan pembangunan infrastruktur guna membuka akses ekonomi di Papua. Meskipun dalam bidang keamanan politik Jokowi masih memerlukan waktu yang lebih untuk menyelesaikan permasalahan ini, tetapi Beliau sudah menunjukkan perhatiannya dengan membebaskan lima tahanan politik (tapol) di Papua pada tahun 2015 lalu.

Secara resmi, telah tercatat bahwa pada tahun 1969 Papua telah menjadi bagian dari Indonesia. Papua merupakan bagian dari kita dan sekaligus keluarga kita. Oleh sebab itu, Pemerintah Indonesia diharapkan dapat meningkatkan human security di Papua, sehingga tidak ada lagi orang Papua yang selama hidupnya merasa terancam dan tertekan. Hal ini dapat diwujudkan diantaranya dengan :

1. Memberikan perhatian yang lebih terhadap keamanan politik di Papua melalui adanya pengawasan secara khusus terhadap hak asasi manusia. Hal ini dapat diwujudkan melalui adanya keterbukaan akses terhadap badan pengawas hak asasi manusia dan para jurnalis;

2. Melihat sampai saat ini orang-orang Papua masih merasa hidup dalam tekanan dan ancaman, pemerintah dapat mengurangi jumlah pasukan militer yang berada di Papua;

3. Pemerintah Indonesia juga harus mendorong kesadaran seluruh elemen negara untuk menghargai dan menghormati hak asasi manusia, khususnya bagi orang Papua asli;

4. Sebagai bentuk keterbukaan, Pemerintah Indonesia juga dapat menyediakan transparansi terhadap catatan keamanan politik di Papua.

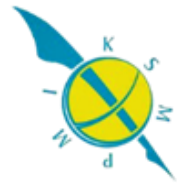

